\title{
Pituitary Gland Acidophil Adenoma
}

National Cancer Institute

\section{Source}

National Cancer Institute. Pituitary Gland Acidophil Adenoma. NCI Thesaurus. Code C6780.

An epithelial neoplasm of the anterior pituitary gland in which the neoplastic cells stain positive with acidic dyes. 